\title{
The Relationship of Nutritional Status and Perineal Wound Healing Among Post-Partum Women
}

\author{
Pipit Festy ${ }^{1}$ Yuanita Wulandari ${ }^{2, *}$ Maghfiratus Syawaliyah ${ }^{3}$ \\ ${ }^{1,2,3}$ Faculty of Health Sciences, Universitas Muhammadiyah Surabaya \\ *Corresponding author. Email: yuanita.ners@fik.um-surabaya.ac.id
}

\begin{abstract}
Postpartum mothers with a history of episiotomy during vaginal delivery are prone to perineal wound infections. Nutritional status has an important role in the process of wound healing. The purpose of this study was to determine the relationship of nutritional status with the process of healing perineal wounds. The research method was conducted with a correlational analytic design with a cross-sectional approach. Purposive sampling was used to select 37 mothers in the postpartum day 5 as a study sample. Data collection was done by observation with a checklist and questionnaire. The variables of this study were the nutritional status and perineal wound healing. The Chi-Square test was used to analyse the data with a significant level of $\rho \leq \alpha(0.05)$. The results of this study stated that there was a relationship between nutritional status and perineal wound healing $(\rho=0.002 ; \mathrm{X} 2=12.282 \mathrm{a})$. It was concluded, that nutritional status is one of the important things that must be considered in perineal wound healing in postpartum mothers. Going forward, it is important to consider factors that affect nutritional status, including cultural matters on post-partum mothers.
\end{abstract}

Keywords: post-partum mothers, nutritional status, perineal wound healing

\section{BACKGROUND}

Perineal wound is an interruption of the perineal tissue that is commonly found in women who have given birth to vaginal delivery. Perineal wound that is not treated properly will become an infection called a purpureal infection. This condition is one of the causes of death in postpartum mothers [1]. Based on the results of the Indonesian Demographic Health Survey (SDKI) in 2016 the incidence of perineal wound infection was as much as $15 \%$ of the number of mothers who delivered vaginal delivery [2]. Purpureal infection is the third leading cause of death in mothers in East Java (2017). Based on the preliminary study that conducted in Kangean Island among 10 postpartum mothers on the 5th day who visited perineal wound care, 8 postpartum mothers were identified showing perineal injury still visible in the proliferation phase and 2 postpartum mothers showing reddish perineal wound conditions and complaints of pain. The incidence of puerperal infection is caused by several factors, and nutritional status is one of the factors. Diet and nutritional status are correlated and those are also influence by culture [3]. Based on the consideration of Indonesian culture regarding postpartum care, further investigation regarding the relationship of nutritional status with the process of healing the perineal wound needs to be done.

Factors that influence the process of perineal wound healing, one of which is nutritional status. Knowledge about the nutritional status of postpartum mothers is very important so that the process of healing perineal wounds from the inflammation phase, the proliferation phase to the maturation phase does not lengthen and there is no purpureal infection [4-6]. Postpartum mothers are advised to fulfil their diet with a balanced diet including: enough carbohydrates, protein, fat, vitamins, and minerals [7]. A balanced diet serves to help the process of metabolism, maintenance and formation of new tissue [8]. A balanced diet is useful for the healing process and for producing sufficient milk in postpartum mothers [9]. In addition, balanced nutrition is also a substance needed by the body for its metabolism [1].

\section{METHODS}

A cross-sectional correlational analytic design was used. 37 postpartum women with specific criteria were selected by purposive sampling. The inclusion criterion were the postpartum mothers who are on 5th days of postpartum, willing to be a respondent, with a history of perineal wound suture, and 17 to 45 years old. While the exclusion criteria were postpartum mothers with a history of anaemia, diabetes mellitus, COPD, hypertension, ischemia, and mental disorders. In this study, the method of purposive sampling was carried out by the researcher, namely by taking respondents or samples of postpartum mothers who were controlling the perineal suture in the healing of the proliferation phase on days 4 to 7 in Primary Health Care, Kangean region as many as 37 people. Nutritional status was a value determined from height and weight. It was measured based on body mass index. Thin $=<18.5$, Normal $=18.5-22.9$, Pre-Obesity $=23-24.9$, Obesity $1=25-29.9$, and Obesity $2 \Rightarrow 30$ were 5 scale of nutritional status. While the wound healing phase was described as the occurrence of an episiotomy wound, so it 
requires a healing process measured based on the condition of the wound that can in 3 phases, namely the inflammatory, proliferation and maturation phases [10]. Assessment of the perineal wound healing level in the proliferation phase on this check list, namely: 1 . The wound heals well, if the value is $>5$ with a dry or wet wound, the perineum wound is closed, there are no signs of infection and there is granulation tissue. 2. The wound heals poorly, if the value is $<5$ the condition of the wound is wet, the perineum wound is open, and there are no signs of infection. The place of research is in the practice of independent midwives on Kangean Island, East Java. The research assistant along with the midwife collected data by visiting the study sample at their respective homes on the 5th day of the postpartum. The research sample has the advantage of obtaining perineal wound care on the 5th day postpartum. The data of this study were analysed using Contingency Coefficient test.

\section{RESULTS \& DISCUSSIONS}

The majority of respondents were $17-26$ years old $(56,7 \%)$, on her 1 st labour experience $(48,7 \%)$, graduated from senior high school $(35,1 \%)$, received monthly income $>1.000 .000$ IDR $(56,8 \%)$, didn't have food abstinence as a part of culture care $(62,2 \%)$, obesity $(54,1 \%)$, and reach the wound healing phase $(67,6 \%)$. This study found that there was correlation between nutritional status and the wound healing phase among 5th days postpartum mothers $(\rho=0,002<\alpha=0,05)$.

In postpartum mother's nutritional status depends on nutritional intake and needs. Continuity between nutritional intake and body needs will produce good nutritional status [7]. The nutritional needs of each individual differ between individuals depending on age, activity, weight, and height [11]. The benefits of balanced nutrition are to accelerate wound healing, so that the duration of perineal wound healing does not occur and prevent infection so that the puerperal mother requires a diet to defend the body against infection. The diet needed by postpartum mothers is the high calories high protein diet where high energy, high protein, high calories, enough minerals and vitamins are given gradually every day to keep the body healthy [11].

One of the factors that influence perineal wound healing is nutritional status and personal hygiene or vulva hygiene. where nutritional status is very influential on the perineal wound healing process for body metabolism and body health, and good vulva hygiene (personal hygiene) can accelerate the healing of perineal wounds, in order to avoid the presence of foreign objects such as dust and germs [5].

The wound healing process must go through certain stages, namely; the inflammatory phase, the proliferation phase and the maturation phase. To support the process of these phases, the wound care worker can modify the food that the postpartum mother eats, but it is still high in carbohydrates and high in protein [9]. In the proliferation phase, new tissue growth occurs through granulation, wound contraction and epithelialization [12]. During granulation, capillaries from around the blood vessels grow to the base of the wound. Healthy granulation tissue is bright red in colour smooth, and the base appears shrivelled and does not bleed easily [13]. After the wound is filled with connective tissue, fibroblasts collect around the wound edge and close the wound edges together [12]. A stronger fibrous epithelial scar tissue forms as the fibroblasts and collagen fibres begin to shrink. Proliferation phase (duration 3-24 days) in which fibroblasts multiply and form migrating tissues or cells. Fibroblasts carry out the synthesis of collagen and mucopolysaccharides [14]. Nutritional status is also very influential in preventing infection, providing comfort, accelerating healing and increasing the volume of breastmilk in postpartum mothers [9].

The results of this study are in accordance with the previous study which stated that there was an effect of nutrition on the healing of perineal wounds in postpartum mothers in Banda Aceh [15]. Poor nutritional status will make the healing process of perineal wounds lengthen. Good nutritional status will affect the speed of healing of perineal suture wounds. Another study also found that the better the intake of nutrients in postpartum mothers, the faster the recovery of perineal wounds $[15,16]$.

The results found that postpartum mothers with underweight, normal and obese nutritional status had poor wound healing which could result in infection. nutritional status that is thin, normal and obese which occurs late wound healing occurs [9]. Those things happen because of postpartum mothers perform food restrictions and the effect is the occurrence of nutritional imbalances in postpartum mothers [12]. In addition, previous labour experience affects care during postpartum. In this study, postpartum mothers who had nutritional status with perineal wound healing rates had not yet reached the wound healing phase.

The results of this study found that there was a relationship between nutritional status and the phase of perineal wound healing in postpartum mothers. Therefore, health workers are expected to pay more attention to the nutritional status of postpartum mothers, especially with perineal suture wounds that are very vulnerable to developing puerperal infections. In addition, health workers are expected to provide education to postpartum mothers and their families to maximize the food consumed by postpartum mothers. 


\section{FIGURES AND TABLES}

Table 1 The characteristics of respondents among postpartum mothers in Kangean Island, East Java (n: 37)

\begin{tabular}{|l|l|l|}
\hline Characteristics of respondents & f & \% \\
\hline Ages & & \\
\hline $17-26$ & 21 & 56,7 \\
\hline $27-36$ & 10 & 27,0 \\
\hline $37-46$ & 6 & 16.2 \\
\hline Labour Experiences & 18 & \\
\hline $1^{\text {st }}$ & 18 & 48,7 \\
\hline $2^{\text {nd }}$ & 9 & 24,3 \\
\hline $3^{\text {rd }}$ & 6 & 16,2 \\
\hline$\geq 4^{\text {th }}$ & 4 & 10,8 \\
\hline Education Background & 8 & \\
\hline Elementary School & 12 & 21,6 \\
\hline Junior High School & 13 & 32,4 \\
\hline Senior High School & 4 & 10,8 \\
\hline Collage & & \\
\hline Monthly Income & 16 & 43,2 \\
\hline$\leq 1.000 .000$ IDR & 21 & 56,8 \\
\hline$>1.000 .000$ IDR & & \\
\hline $\begin{array}{l}\text { Food abstinence as a part of culture } \\
\text { care }\end{array}$ & 14 & 37,8 \\
\hline Yes & 23 & 62,2 \\
\hline No & & \\
\hline Nutritional status & 5 & 13,5 \\
\hline Thin & 12 & 32,4 \\
\hline Normal & 20 & 54,1 \\
\hline Obesity & & \\
\hline Wound healing Phase & 12 & 32,4 \\
\hline $\begin{array}{l}\text { Did not reach the wound healing } \\
\text { phase }\end{array}$ & 25 & 67,6 \\
\hline Reach the wound healing phase & \\
\hline
\end{tabular}

Table 2 Distribution of respondents based on nutrition status with the perineum wound healing phases

\begin{tabular}{|l|c|c|c|}
\hline \multirow{2}{*}{$\begin{array}{c}\text { Nutritional } \\
\text { status }\end{array}$} & \multicolumn{2}{|c|}{ Wound healing Phase } & Total \\
\cline { 2 - 3 } & Reach & $\begin{array}{c}\text { Did not } \\
\text { reach }\end{array}$ & \\
\hline Thin & 0 & 5 & 5 \\
\hline Normal & 10 & 2 & 12 \\
\hline Obesity & 15 & 5 & 20 \\
\hline Total & 25 & 12 & 37 \\
\hline
\end{tabular}

\section{CONCLUSION}

The results of this study found that there was a relationship between nutritional status and the phase of perineal wound healing in postpartum mothers. Therefore, health workers are expected to pay more attention to the nutritional status of postpartum mothers, especially with perineal suture wounds that are very vulnerable to developing puerperal infections. In addition, health workers are expected to provide education to postpartum mothers and their families to maximize the food consumed by postpartum mothers.

\section{AUTHORS' CONTRIBUTIONS}

Pipit Festi W, Yuanita Wulandari, and Maghfiratus Syawaliyah were conceived of the presented idea and developed the concepts.

Pipit Festy and Yuanita Wulandari were wrote the manuscript.

Pipit Festy and Maghfiratus Syawaliyah were performed the analytic calculations.

Maghfiratus Syawaliyah was apply for a research permit \& collected the data.

\section{ACKNOWLEDGMENTS}

Thanks deliver to the samples and their family, the head of primary health care in Kangean, and the midwiferies who are willing to provide information related to the availability of samples.

\section{REFERENCES}

[1] Manuntungi A E, Irmayanti and Ratna 2019 Factors Affecting the Duration of Healing of Perineal Wounds in Post-partum Women in the Nursing Room at Mitra Manakarra Mamuja Hospital Nurs. Insid. Community 1

[2] Puspitaningsih 2017 Factors Affecting Mother's Knowledge About Fulfilling the Nutritional Needs of Postpartum Mother Hosp. Majapahit 9

[3] Rahmawati E and Triatmaja, N T 2015 The Relationship between Maternal Nutrition and Perineal Wound Recovery J. Wiyata Penelit. Sains Kesehat. 2

[4] Moloku F, Wantouw W and Sambeka J 2013 The Relationship between Knowledge About Treatment and Episiotomy Wound Healing in Post-Patum Mothers in Inpatient Room D Lower Hospital Prof. R. D Kandau Malalayang. J. Keperawatan 1

[5] Hasnidar 2018 Factors Associated with the Healing of Perineal Stitch Wounds in Postpartum Women at UPTD Puskesmas Watampone J. Ilm. Kesehat. Diagnosis 3

[6] Rismawanti V and Yulizawati 2012 The Relationship Between Postpartum Attitude Toward Balanced Nutrition and Perineal Wound Healing at the Khairunnisa Maternity Clinic J. Ilm. Bidan 3

[7] Endah E and Rizkyana S 2014 The Relationship between Post-Partum Nutrition Pattern and Perineal Stitch Wounds Healing in the Bajulmati Health Center Work Area Health (Irvine. Calif). 3

[8] Jaelani A K, Putri M and Lubis N A 2017 The Relationship between Postpartum Mother Knowledge About Nutritional Food Balanced with Perineal Wound Healing J. Endur. 2 
[9] Rini D 2013 The Relationship Between Nutritional Status of Post-partum Women and Perineal Wound Healing in the Work Area of Cukir District Health Center, Jombang Regency J. Metab. 2

[10] Wiliyanarti P F 2018 Nutrition and Diet (Surabaya: UMSurabaya Publishing)

[11] Sakinah T P, Kartini and Aswita 2017 The Relationship between Postpartum Nutritional Status and Food Culture during the Postpartum Period with the Healing of Perineal Wounds at Dewi Sarika Hospital. Kediri (Poltekkes Kemenkes Kendari)

[12] Hartiningtiyaswati S 2010 The Relationship between Food Abstinence Behavior and Perineal Wound Healing Time in Postpartum Women in Srengat District, Biltar Regency Blitar

[13] Tirtaningsih 2017 The Relationship between Vulva Hygiene and Perineal Wound Healing Process in Post-partum Women at the BKIA Poly, Muhammadiyah Hospital (Universitas Muhammadiyah Surabaya)

[14] Erma Mexcorry Sumbayak 2016 Fibroblasts: Their Structure and Role in Wound Healing J. Kedokt. Meditek 21

[15] Rahmawati E and Triatmaja, N T ). The Relationship between Maternal Nutrition and Perineal Wound Recovery J. Wiyata Penelit. Sains Kesehat. 2

[16] Rismawanti V and Yulizawati 2012 The Relationship Between Postpartum Attitude Toward Balanced Nutrition and Perineal Wound Healing at the Khairunnisa Maternity Clinic J. Ilm. Bidan 3 